\title{
The concept of management by flexible goals
}

Prof. Kazimierz Krzakiewicz Poznań University of Economics

Prof. Szymon Cyfert Poznań University of Economics

\section{Introduction}

In line with the assumptions of the shareholder value concept, which in the management literature is presented as a pragmatic approach to management, and which is an expression of a kind of utilitarianism, existence of Organizations is perceived as protection of investor interests (Cyfert, Krzakiewicz 2009).

Anything that in market economy is considered a condition for organization operation, in the shareholder value concept is the main goal of organization operation. This means that the main goal and indirect goals trade places and as a result the reason for the existence of the organization can be easily overlooked.

This observation helps conclude that the approach to organization management, dominant today, must be changed. While emphasizing the validity of that conclusion it must be observed that in the last decades economic conditions, mechanisms of market play and value systems shared by societies changed radically. On the other hand, the methods and principles of management remained unchanged. The approach to the formulation of objectives and strategies, approval of tasks, design of employee 
appraisal systems, motivation and budgeting as well as the approach to the management process must be verified.

At the same time management practice shows that Organizations which decide to abandon centrally approved plans, individual productivity assessments, standard planning, budgets and other typical activities, prove to be more effective in the long run than their competitors, which helps to conclude that what is needed in modern organization is more leadership and less central planning. Organizations, which wish to maintain their competitive advantage over a long period of time, need not focus their attention and energy internally on the internal demonstration of productivity but externally - on the market, competitors and consumers.

This article is the authors' contribution to the debate on changes in management processes of modern organizations. The authors present the assumptions of the management concept based on flexible goals (management by flexible goals).

\section{Operating conditions of modern organizations as the basis of the management process based on flexible goals}

The approach to management based on flexible goals is connected with the work of the interdisciplinary team Beyond Budgeting Round Table (BBRT), which was formed to develop a model of organization management that would favour long term competitiveness in complex and turbulent conditions prevailing in the community. The team tries to answer the question whether management without formulation and approval of budgets, "plan - execution" type of control, centrally approved objectives, more and more often addressed in the literature, is at all possible (Krupski 2005). At the same time it is pointed out in the literature that value systems and interpersonal relations are becoming central problems in the management science. There is a specific value system and philosophy of action behind each objective, each effectiveness norm, and each task given and accepted. However, more too often attempts are made to solve problems of the $21^{\text {st }}$ century by reference to the philosophy and values dominant at the beginning of the $20^{\text {th }}$ century.

The new model of the approach to management is based on the profound belief that competitive advantage is based on members of the organization, and, more specifically, on their creativity, involvement and ability to think rationally. There are organizations, particularly in the service sector, which are based on knowledge in which each member is a kind of information 
centre. In unpredictable and dynamically changing conditions prevailing in the environment, only the organizations which will be able to effectively implement the managerial processes without significant involvement of top management will stand a chance for survival. In a complex environment the potential of development will be opened only to the companies which will have a relevant level of complexity and which will be able to stimulate development processes by using innovation.

Most such organizations operate as networks of partners in which strategic decision making processes have been decentralized and are based on periodical meetings of partners. The structure of the organizations which implement the management by flexible goals model should be made up of "sets" of small teams, responsible for the effects of their work and for their management. Such organization of a corporation, assuming elimination of classical, functional organizational units, requires each participant of the corporation to perform entrepreneurial functions.

\section{An organizational model implementing the management by flexible goals process}

In an organization, which implements the management by flexible goals process, the tasks and the role of the strategic top management should be revalued. Instead of developing a strategy and business model, make objectives operational and set directions of actions, management members should become advisors, recipients of principles, promoters of action. Implementation of such change requires building an organizational culture based on strong values and principles of operation (Cyfert, Krzakiewicz 2009).

A set of "critical success factors" can be identified, which assume specific meaning in the model of organization which implements the management by flexible goals model:

- quick response - in order to adapt to continuous changes on the global market,

- innovation - ensuring possibility of coping with the shortening life cycles of products and technologies,

- operational advantage - to support competition under price war conditions,

- proximity to customer - to attract and retain less loyal and more niche customers,

- care for personnel - to attract and retain employees with the highest qualifications, 
- ethical organizational behaviour - to ensure compliance with the growing requirements of social community.

The management by flexible goals model can be presented as a "positive feedback loop" (fig. 1).

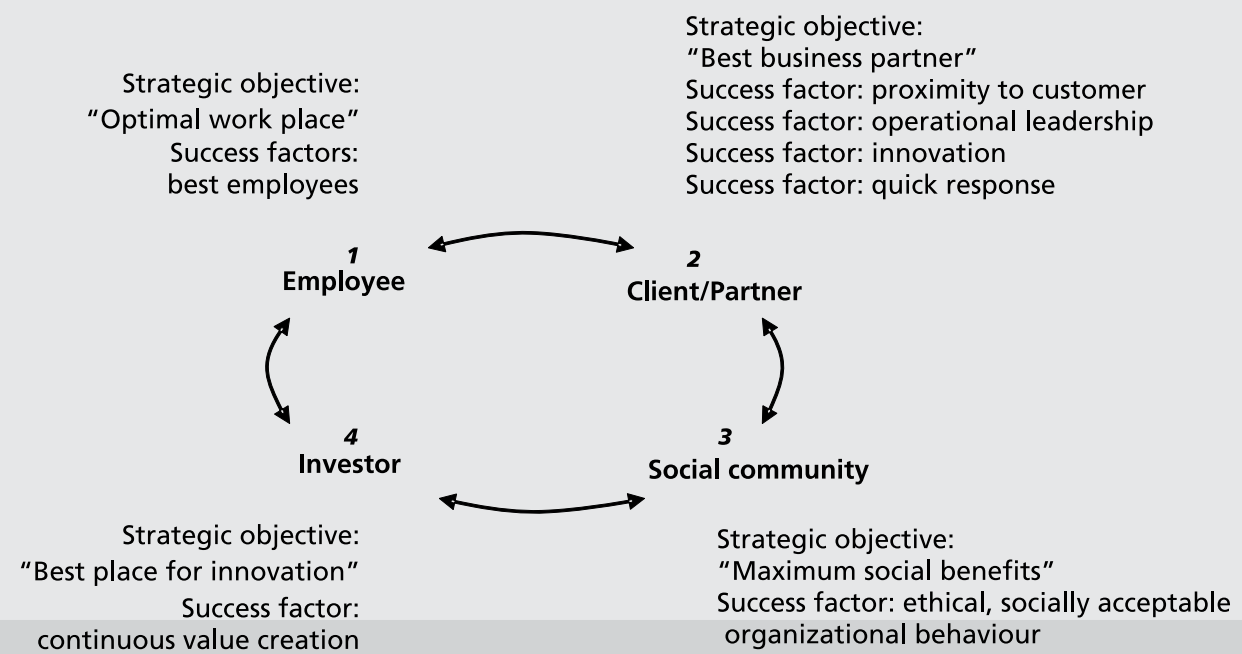

Figure 1. Use of the "positive feedback loop" in the management by flexible goals model

Source: prepared by the authors

A model of organization implementing the management by flexible goals process is based on the assumption that it is necessary to ensure decentralization and autonomy, implement new management instruments and at the same to "de-learn" the old methods and behaviours. Also the approach to HR management must be changed. The classical approach assumed that employees must be treated like children - held by hand and continuously controlled. The new model assumes that all the employees think like entrepreneurs and, deep in their souls, they are entrepreneurs. This means that members of the organization must be treated in line with the " $Y$ " theory - as people who are internally positively motivated, capable of self-management, who can be trusted, as talented individuals, who want to contribute to the success of the organization, who look for recognition, accountability and meaning in their work. This is in line with the assumptions of a knowledge based organization (table 1). 
Table 1. Approach to organization management in knowledge based economy

\begin{tabular}{l|l}
\hline Features of knowledge based economy & Critical success factors of the organization \\
\hline 1. Discreet changes & - Quick response \\
\hline 2. Short life cycles & - Innovation \\
\hline 3. Continuous price decrease & - Operational leadership \\
\hline 4. Weakening customer loyalty & - Proximity to customer \\
\hline 5. Selection of employees & - Best co-workers \\
\hline $\begin{array}{l}\text { 6. Requirement of transparency, social } \\
\text { responsibility }\end{array}$ & $\begin{array}{l}\text { - Ethical, socially accepted organizational behaviour } \\
\text { - Stable value creation }\end{array}$ \\
$\begin{array}{l}\text { 7. Expectation of high financial results } \\
\text { - Power in customer's hands" }\end{array}$ & $\begin{array}{l}\text { - strong competition } \\
\text { - individual consumer demand } \\
\text { - decentralization and adaptation }\end{array}$ \\
\hline
\end{tabular}

Source: prepared by the authors

Building an organization based on flexible goals requires rejection of a number of myths lying at the basis of the traditional approach to organization management:

1. "Value for shareholders or economic added value is the main reason for an organization", while the economic added value is not an aim but effect, which complements the condition of economic operations.

2. "Organizations should present earnings guidance to capital markets, which gives them benefits", while presentation of future results to shareholders and analysts actually means "making empty promises". Many leading companies (e.g. Porsche, Google, Coca Cola, Citigroup) abandoned this practice since they noticed that it most often ends with a fatal "play with figures".

3. "Growth and income are the most important success measures", while growth in most organizations and sectors should be a secondary objective. Growth is a good indicator of an effective creation of value and high competitiveness in the organizations, which highly value ethical organizational behaviour.

4. "Productivity of each employee can be assessed", while in reality it is not possible in most organizations. This inability is the result of making results dependant on interaction between different participants of the process and not on independent actions of individual units. 
5. "Correctly selected indicators will give the manager the possibility to effectively manage the organization", while the system of measures can at best allow for the definition of the directions of action and does not answer the question what should be done. The value of the measure system is conditioned by the ability to encourage participants of the organization to ask questions about the way in which the organization functions. However, in a situation in which the measures are treated as objective and absolute, they can pose a hazard to the operation of the organization.

6. "Effectiveness of organization depends primarily on the work of managers", while those "heroic" managers are not effective under turbulent and complex conditions. Erring is the feature that distinguishes modern managers.

7. "Reasons for the low effectiveness of organization should always be looked for in the work of the employees", while two questions should rather be asked: what prohibits people or teams from achieving high results and how the system should be changed so that members of the organization get the possibility to prove their effective operation. A study conducted by Deming revealed that $95 \%$ of all problems in the organization are due to the system and only 5\% are due to people (Walton, Deming, 1996), which means that if we attribute all problems to people, we do not notice $95 \%$ possibilities of improvement.

\section{An agreement about relative improvement}

Building of a new management model for an organization requires solution of two significant problems. First, the model of the organization which pursues the process of management based on flexible goals with the help of the "old lexicon", based on the assumptions of the mechanistic model, cannot be effectively described. Secondly, it can be noticed that highly effective organizations of the $21^{\text {st }}$ century "do not know what they do". These organizations have developed their processes and management models on the basis of the intuition of their founders, owners or managers, without any help of external consultants, without any scientific base and without any ultimate vision of operation. However, an analysis of the management practice helps to draw a conclusion that with reference to the phenomena described above changes can be observed and they are expressed in the principle which can be called "an agreement about relative improvement" (Pfläging 2012, p. 32), which is the core of the concept of management based on flexible goals. 
The agreement about relative improvement is based on the observation that it is irrational to give objectives to the managers and teams of employees, which have been developed without their participation, and subsequently assess their actions based on their compliance (or non-compliance) with these objectives. The agreement assumes that the management's job is to work out an appropriate organizational culture which emphasizes motivation, through which members of the organization will assume responsibility for the continual improvement of productivity. Under such conditions decentralized decisions will be made quickly and optimally owing to direct contacts with external and internal stakeholders.

The agreement about relative improvement is based on mutual trust. Ensuring a high level of transparency in the operation of the organization and increased expectations with reference to work teams and managers are significant challenges. These challenges can be coped with owing to the high level of trust and acceptance of team and individual responsibility. Owing to trust, responsibility for the effectiveness of work and quality of decisions is gradually shifted from the centre to the lower levels in the organization, which leads to significant changes in the management process and remodelling of the organizational culture.

\section{Principles of management based on flexible goals}

The management by flexible goals concept comprises 12 fundamental principles of management - the first six principles form conditions for leadership action based on extensive empowerment of internal organizational units and for radical decentralization of management:

1. Customer orientation - increased level of customer satisfaction (instead of maximization of hierarchically determined goals).

2. Responsibility - creation of a new network made up of small organizational units, responsible for the results of their operations (in place of centralized hierarchy).

3. Success favouring environment - favouring growth, market success, organization of the environment (in place of the achievement of internal goals "irrespective of the price" of their effectiveness).

4. Freedom of operation - empowering teams having direct contacts with the customer (in place of supervision, strict control, top-down interference and absolute adherence to plan). 
5. Flexible management team - managed based on clearly formulated goals, value systems and threshold conditions (in place of detailed instructions and budgets).

6. Transparency - information generally available (in place of restricted access to information and shaping organizational position and status based on access to information).

The other set reflects the flexibility of management processes in the organization:

1. Flexible formulation of objectives - formulation of ambitious, flexible goals, continuously improvement oriented (in place of incremental objectives approved by top management, which must be accomplished by specific deadlines).

2. Flexible motivation system - evaluation of the overall success and remuneration linked to continuous improvement (in place of motivation based on the achievement of individual, approved objectives).

3. Flexible planning - planning as a creative and continuous process, action oriented (in place of planning as day to day operation in the hierarchical system, where members of the organization are divided into "planners" and "executors").

4. Flexible control - control based on relative indicators of effectiveness connected with market conditions, interpersonal relations, previous periods of activity and prospects of changes (in place of the control of deviations approved indicators of goal achievement).

5. Flexible resource management - ensuring access to resources as and when needed, without any anticipatory detailed planning (in place of annual reports on budget delivery, distribution of resources and their adaptation by delegation).

6. Flexible coordination - dynamic, horizontal, market linked coordination (in place of annual planning cycles and coordination based on hierarchy).

No strategic plan is created in such processes of organization management. All organizational units have their own, flexible plans of operation based on the use of opportunities existing in the environment (fig. 2) (Krupski 2005; Krzakiewicz, Cyfert, Kraśniak 2006).

In recent years shareholder value has become the doctrinal aim for many companies. The concept of shareholder value, which is sometimes presented as a rational and pragmatic approach to organization management, is in fact extremely utilitarian and mechanistic. Use of this concept in management 


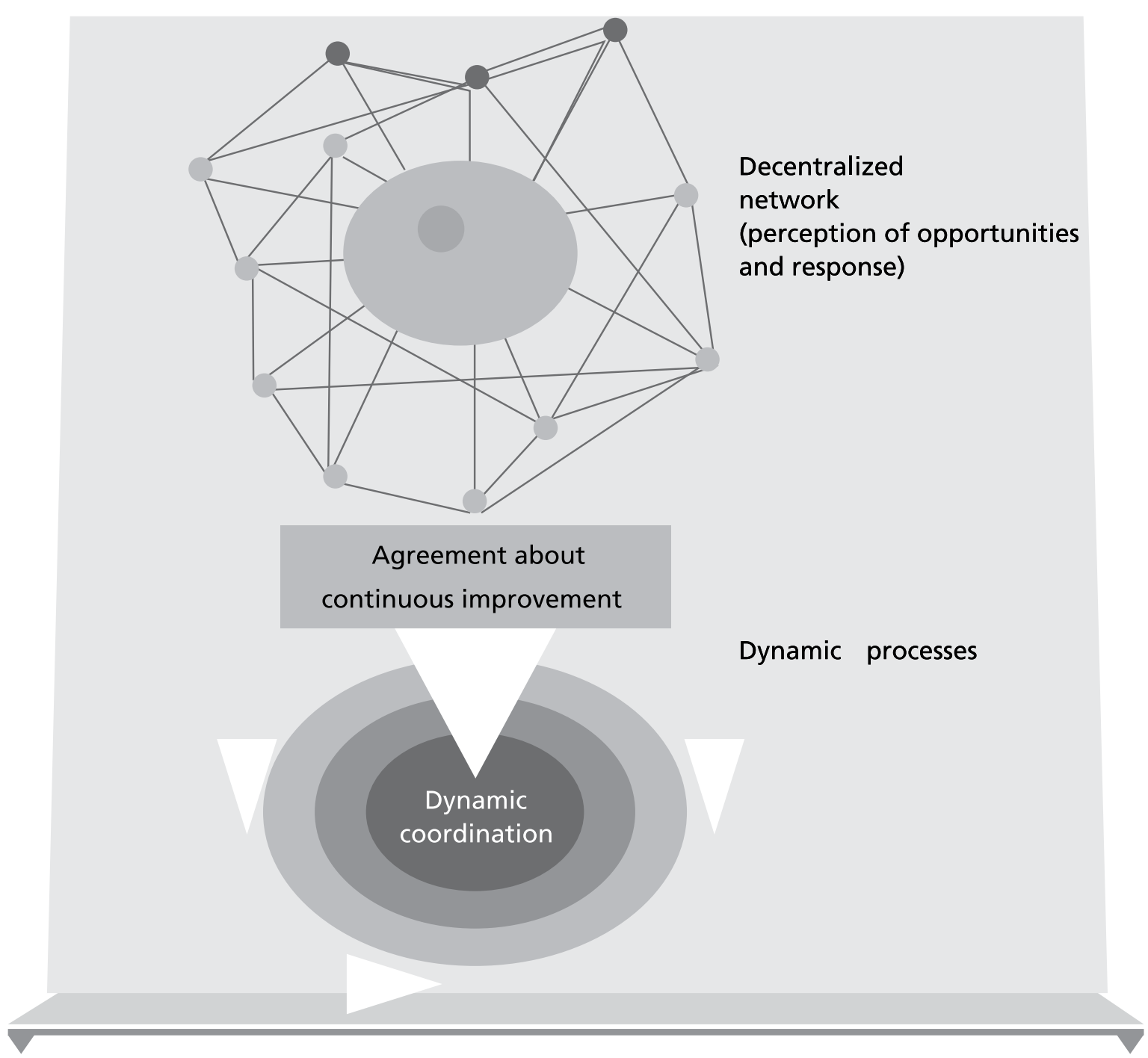

Figure 2. Model of organization management based on flexible goals

Source: prepared by the authors

processes means that companies are a kind of "money making machines", and work only for the interest of shareholders. In this way a vitally important but actually not fundamental condition for the capability of operating under market conditions, is interpreted as the main objective of the organization. The aim and the means trade places, and in such conditions it is easy to lose sight of the real "existence" of the organization (Pfläging 2012, p. 6). Customers and values created for them became the means to satisfy the needs of the 
organization ("We want to create value and therefore we must sell products and services") unlike in the past when organizations were the means to satisfy the needs of customers ("We want to serve customers by creating value for them"). Organizations became the most important goal for themselves and do not pay any attention to anything else - be it members of the organization, or customers or social environment.

The reductionist, Cartesian model of thinking, characteristic of the creation of shareholder value, was indirectly supported - the support resulted from the success of the concept of a balanced system of indicators. When maps of strategies advanced by R. Kaplan and D. Norton were created, thinking was structured with the help of a causal chain between success factors at the end of which (at least for profit oriented organizations) there was a financial result (Norton, Kaplan 2010). Interdependencies between the factors which are beyond this relation, going in one specific direction, are not considered and the "existence" is ultimately outside the boundaries of strategic maps since it cannot be presented on the map in the form of tangible variables. This leads to the situation in which means leading to the aim and the aim of the existence of an organization are merged or change places, which ultimately deprives members of the organization of true, social and moral responsibility. Organizations as such do not take any action. All action is done by people, members of the organization. They make decisions and take responsibility for their organizational behaviours.

\section{Instead of conclusion - a prospective change of the organizational culture}

Most programs aimed at the development of culture, vision and mission implemented in organizations do not have any meaning for the day to day work of managers and excessively absorb the attention of organization members. These programs are burdened with a significant fault - in the vision and mission an attempt is made to define pragmatic business objectives of the organization and all actions taken by the organization should be taken to achieve them. This means that they lack the meaning of the existence of the organization. This leads to limited formulation of alternative visions of development and new ideas, which ultimately restricts freedom in decision making processes.

In the traditional approach to management important problems from the strategic perspective are often avoided in favour of short term benefits and ethics is moved to the background. This means that the development of culture 
and processes which would make the organizations and their members act ethically and be long term oriented is a serious challenge for modern organizations.

\section{Summary}

\section{The concept of management by flexible goals}

The aim of this paper is to contribute to the debate on the directions of change of contemporary organizations and present assumptions of a management concept based on flexible goals. The paper starts with the presentation of conditions in which modern organizations operate. It is followed by the discussion of the essence of the concept of governance based on flexible goals and description of the principle of agreement about relative improvements. Finally, a model of the organization implementing the management process based on flexible goals is presented and the rules of management based on flexible goals are defined.

Keywords: flexibility of the organization, process management, strategic objectives.

\section{Streszczenie}

\section{Koncepcja zarządzania w oparciu o elastyczne cele}

Celem artykułu jest włączenie w dyskusję nad kierunkami zmian w procesach zarządzania współczesnymi organizacjami i przedstawienie założeń koncepcji zarządzania w oparciu o elastyczne cele. Punktem wyjścia w artykule uczyniono zarysowanie uwarunkowań funkcjonowania współczesnych organizacji. Na tym tle omówiono istotę koncepcji zarządzania w oparciu o elastyczne cele, scharakteryzowano zasadę porozumienia dotyczącego względnego udoskonalenia, przedstawiono model organizacji realizującej proces zarządzania oparty na elastycznych celach i zdefiniowano zasady zarządzania w oparciu o elastyczne cele.

Słowa

kluczowe: elastyczność organizacji, proces zarządzania, cele strategiczne.

\section{References}

1. Cyfert Sz., Krzakiewicz K. (2009), Nauka o organizacji, TNOiK, Poznań.

2. Handy Ch. (1999), The Hungry Spirit. Purpose in the Modern World, Broadway. 
3. Krupski R. (2005), Zarządzanie przedsiębiorstwem w turbulentnym otoczeniu. Ku superelastycznej organizacji, PWE, Warszawa.

4. Krzakiewicz K., Cyfert Sz., J. Kraśniak (2006), Zmiany w systemach planowania i organizowania polskich przedsiębiorstw, "Przegląd Organizacji”, No. 2.

5. Mintzberg H. (2008), Strategy Bites Back! It is Far More and Less Than You Have Ever Imagined, Prentice Hall, New York.

6. Norton Kaplan D. (2010), Wdrażanie strategii dla osiagnięcia przewagi konkurencyjnej, PWN, Warszawa.

7. Pfläging N. (2012), Führen mit flexiblen zielen beyond budgeting in der praxis, Campus Verlag GmbH, Frankfurt/Main.

8. Walton M., Deming W.E. (1996), The Deming management method, Dodd, New York. 